\title{
KEANEKARAGAMAN JENIS TUMBUHAN DAN SIMPANAN KARBON PADA BERBAGAI TIPE PENGGUNAAN LAHAN DI KABUPATEN PESISIR BARAT PROVINSI LAMPUNG
}

\author{
The Diversity of Plant and Carbon Stock in Various Types of Land Use in Pesisir Barat \\ Regency of Lampung Province
}

Dian Ariyanti ${ }^{{ }^{*}}$, Nurheni Wijayanto ${ }^{2}$, dan Iwan Hilwan ${ }^{2}$

(Diterima Juli 2018 / Disetujui September 2018)

\begin{abstract}
Vegetation is one factor that can decrease carbon accumulation in the atmosphere. The diversity of plant species in each land use has different abilities to absorb carbon in the atmosphere. This research was conducted in Pesisir Barat Regency of Lampung Province on 4 (four) types of land use, namely: (1) natural forest in Balai Kencana Resort, Bukit Barisan National Park (2) oil palm plantation in Pekon Marang, (3) coffee plantation in Pekon Suka Mulya, and (4) agroforestry of repong damar in Pekon Pahmungan. This reserach aims to analyze the diversity of plant species and to calculate the potential of plant carbon stock and carbon sequestration (above ground biomass) using alometric equations in various types of land use in Pesisir Barat Regency. The research method was vegetation analysis to learn about the diversity of plant species and calculation of carbon stock using alometric equations. The results showed that the composition of plant species in Bukit Barisan NP found 83 plant species belonging to 37 families, in the palm plantation found 9 plant species belonging to 8 families, in the coffee garden found 17 plant species belonging to 11 families, and in agroforestry of repong damar found 73 plant species belonging to 33 families. The total carbon stock potential was $376.16 \mathrm{ton} / \mathrm{ha}$ and carbon sequestrated. 1257.20 ton/ha with the highest carbon uptake available at repong damar agroforestry site of 901.11 ton/ha.
\end{abstract}

Key word: aboveground biomass, carbon, diversity, pesisir barat regency

\section{PENDAHULUAN}

Isu pemanasan global yang berkembang akhir-akhir ini menjadi perhatian banyak pihak merupakan salah satu penyebab dari perubahan iklim. Pemanasan global telah memengaruhi ekosistem bumi akibat meningkatnya konsentrasi gas rumah kaca (GRK). Sektor kehutanan menyumbang $80 \%$ dari total emisi GRK (Bappenas 2010). Deforestasi dan degradasi hutan merupakan penyebabnya. Laju deforestrasi di Indonesia pada tahun 2015-2016 mencapai 630000 ha. (KLHK 2017).

Kabupaten Pesisir Barat berada di Provinsi Lampung memiliki luas $\pm 2907.23 \mathrm{~km}^{2}$ atau $8.39 \%$ dari luas wilayah Provinsi Lampung dengan berbagai tipe penggunaan lahan (Bappeda Kab. Pesisir Barat 2015). Tipe pengunaan yang ada diantaranya hutan alam, perkebunan dan agroforestri. Sistem agroforestri yang ada dikenal dengan repong damar.

Repong damar merupakan istilah yang digunakan masyarakat lokal dalam menyebut kebun damar yang terletak di kawasan hutan Taman Nasional Bukit

1 Mahasiswa Pascasarjana PS Silvikultur Tropika, Fakultas

Pascasarjana, IPB

* Penulis korespondensi:

e-mail : ariyantidian@gmail.com

2 Staf Pengajar Dept. Silvikultur, Fakultas Kehutanan, IPB
Barisan Selatan yaitu di zona tradisional yang ditetapkan seluas 2433 ha (Yulizar et al. 2014) serta di lahan yang dibudidayakan oleh masyarakat di sekitar kawasan konservasi sebagai kawasan penyangganya. Pola agroforestri memiliki keanekaragaman hayati dan kandungan biomassa yang tinggi karena dapat menyerap karbon jauh lebih besar daripada tanaman semusim (Takimoto et al. 2009). Tipe penggunaan lahan lainnya yaitu perkebunan seperti sawit dan kopi. Beberapa lahan yang awalnya merupakan lahan repong damar telah berubah fungsi menjadi penggunaan lainnya seperti perkebunan sawit. Fenomena illegal logging yang dipicu tingginya permintaan dan harga jual kayu damar memengaruhi kelestarian repong damar.

Keanekaragaman jenis tumbuhan pada berbagai tipe penggunaan lahan di Kab. Pesisir Barat ini tentunya mempunyai kemampuan menyerap dan menyimpan karbon yang bervariasi karena jenis tumbuhan penyusunnya yang berbeda. Penghitungan karbon tersimpan pada berbagai macam penggunaan lahan dapat menggambarkan berapa banyak karbondiokasida $\left(\mathrm{CO}_{2}\right)$ di atmosfir yang diserap oleh tumbuhan tersebut. Besarnya cadangan karbon antar lahan berbeda-beda, tergantung pada keanekaragaman dan kerapatan tumbuhan yang ada, jenis tanahnya serta cara pengelolaannya (Hairiah et al. 2011). Tujuan penelitian ini adalah menganalisis keanekaragaman jenis tumbuhan dan menghitung potensi simpanan karbon 
serta serapan $\mathrm{CO}_{2}$ (di atas permukaan tanah) menggunakan persamaan alometrik pada berbagai tipe penggunaan lahan.

\section{METODE PENELITIAN}

\section{Tempat dan Waktu}

Penelitian dilakukan di Kab. Pesisir Barat Prov. Lampung pada 4 (empat) tipe penggunaan lahan yaitu: (1) hutan alam di Resort Balai Kencana, Seksi Pengelolaan Taman Nasional Wilayah III Krui, Balai Besar Taman Nasional Bukit Barisan Selatan, (2) kebun sawit di Pekon Marang Kec. Pesisir Selatan, (3) kebun kopi di Pekon Suka Mulya Kec. Lemong, dan (4) agroforestri repong damar di Pekon Pahmungan Kec. Pesisir Tengah (Gambar 1). Waktu penelitian bulan Mei 2017-Juli 2017.

\section{Prosedur Penelitian}

Lokasi penelitian ditentukan secara purposive sampling yaitu menggunakan stratifikasi berdasarkan peta tutupan lahan (land cover) (BSN 2011). Petak ukur berukuran $100 \mathrm{~m}$ x $20 \mathrm{~m}$ dengan metode kombinasi antara jalur dan garis berpetak BSN 2011). Petak ukur sebanyak 5 terbagi ke dalam 5 plot berukuran $20 \mathrm{~m}$ x 20 $\mathrm{m}$ dan masing-masing plot dibagi ke dalam sub plot untuk tiap tingkatan pertumbuhan yaitu (a) $20 \mathrm{~m} \mathrm{x} 20 \mathrm{~m}$ untuk tingkat pohon, (b) $10 \mathrm{~m}$ x $10 \mathrm{~m}$ untuk tingkat tiang, (c) $5 \mathrm{~m} \mathrm{x} 5 \mathrm{~m}$ untuk tingkat pancang, (d) $2 \mathrm{~m} \times 2$ $\mathrm{m}$ untuk tingkat semai, tumbuhan bawah, semak, dan herba, dan (e) $1 \mathrm{~m} \times 1 \mathrm{~m}$ untuk pengambilan sampel tumbuhan bawah dan serasah, sebanyak 3 plot pada masing jalur yaitu pada petak ukur ke-1, ke-3, dan ke-5. Penempatan unit contoh dilakukan dengan teknik sampling berupa systematic sampling with random starts yaitu peletakan petak ukur pertama dilakukan secara acak dan petak ukur berikutnya diletakan secara sistematik. Jarak antar jalur adalah 100 m (Gambar 2).

Data analisis vegetasi yang dicatat adalah nama jenis, jumlah, diameter, tinggi total, dan tinggi bebas cabang. Pengukuran biomassa pohon, tumbuhan bawah, serasah, dan pohon mati menurut BSN (2011). Pengukuran biomassa pohon dilakukan dengan

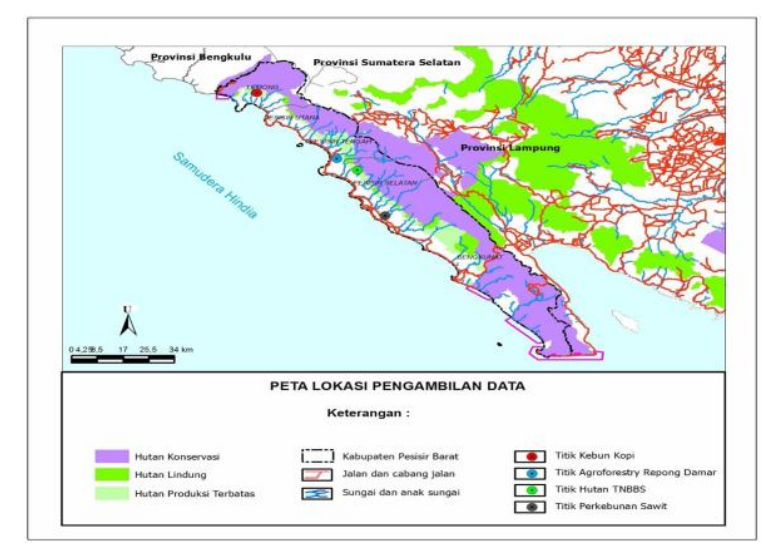

Gambar 1 Peta lokasi pengambilan data penelitian mengukur diameter batang setinggi dada (dbh) atau ketinggian $1.30 \mathrm{~m}$ dari atas permukaan tanah dan menghitung biomassa pohon dengan persamaan alometrik.

Pengukuran biomassa tumbuhan bawah dan serasah dilakukan metode destructive sampling dengan menebang semua bagian tumbuhan bawah di atas permukaan tanah serta mengumpulkan serasah yang ada dalam plot pengukuran dan menimbang berat basahnya. Berat kering diukur dengan mengambil contoh sebanyak $\pm 300 \mathrm{~g}$ kemudian di oven dengan suhu $85^{\circ} \mathrm{C}$ selama 48 jam. Pengukuran biomassa pohon mati dilakukan dengan mengukur dbh pohon mati dan menentukan tingkat keutuhan pohon mati berdasarkan BSN (2011). Pengukuran biomassa kayu mati dilakukan berdasarkan volume.

\section{Analisis Vegetasi}

\section{Indeks nilai penting}

Nilai dominansi suatu jenis di setiap tingkat pertumbuhan diketahui dengan metode Indeks Nilai Penting (Muller-Dombois \& Ellenberg 1974):

$$
\begin{array}{cl}
\text { INP untuk tiang dan pohon } & =\mathrm{KR}+\mathrm{FR}+\mathrm{DR} \\
\text { INP untuk semai dan pancang } & =\mathrm{KR}+\mathrm{FR} \\
\text { Ket: KR } & =\text { Kerapatan Relatif } \\
\text { FR } & =\text { Frekuensi Relatif } \\
\text { DR } & =\text { Dominansi Relatif }
\end{array}
$$

\section{Indeks keanekaragaman jenis}

Menurut Ludwig \& Reynold (1988) perhitungan menggunakan persamaan indeks Shannon-Wienner sebagai berikut:

$$
H^{\prime}=-\sum_{i=1}^{s}\left(\frac{n i}{N}\right) \ln \left(\frac{n i}{N}\right)
$$

H' adalah indeks keanekaragaman jenis ShannonWienner, $\mathrm{n}_{\mathrm{i}}$ adalah jumlah individu jenis ke-i, $\mathrm{N}$ adalah jumlah individu seluruh jenis, $S$ adalah jumlah jenis yang ditemukan. Kriteria nilai indeks keanekaragaman jenis $\left(\mathrm{H}^{\prime}\right)$ yaitu rendah jika nilai $\mathrm{H}^{\prime}<2$, sedang jika nilai $\mathrm{H}^{\prime} 2-<3$, dan tinggi jika nilai $\mathrm{H}^{\prime} \geq 3$.

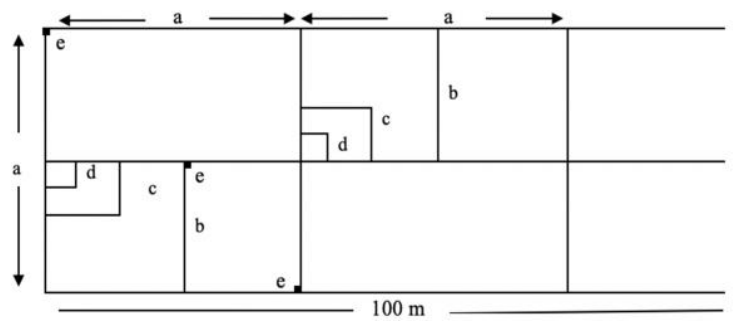

a. $20 \mathrm{~m} \times 20 \mathrm{~m}$ untuk tingkat pohon

b. $10 \mathrm{~m} \times 10 \mathrm{~m}$ untuk tingkat tiang

c. $5 \mathrm{~m} \times 5 \mathrm{~m}$ untuk tingkat permudaan pancang

d. $2 \mathrm{~m} \times 2 \mathrm{~m}$ untuk tingkat permudaan semai dan tumbuhan bawah

e. $1 \mathrm{~m} \times 1 \mathrm{~m}$ untuk pengambilan sampel tumbuhan bawah dan serasah

Gambar 2 Desain unit contoh vegetasi di lapangan 


\section{Indeks kekayaan jenis}

Indeks kekayaan jenis pada suatu habitat dapat diketahui dengan menggunakan indeks kekayaan Margalef (1958) sebagai berikut:

$$
R 1=\frac{S-1}{\ln (N)}
$$

$\mathrm{R} 1$ adalah indeks kekayaan jenis, $\mathrm{S}$ adalah jumlah spesies, $\mathrm{N}$ adalah jumlah individu.

\section{Indeks kesamaan komunitas}

Besarnya indeks kesamaan komunitas dihitung menggunakan rumus (Odum 1993):

$$
I S=\frac{2 C}{A+B}
$$

IS adalah indeks kesamaan komunitas, $\mathrm{C}$ adalah jumlah spesies yang sama dan terdapat pada kedua komunitas, A adalah jumlah spesies di dalam komunitas A, B adalah jumlah spesies di dalam komunitas B.

\section{Pendugaan biomassa (di atas permukaan tanah)}

Perhitungan biomassa tumbuhan bawah dan serasah menggunakan rumus Hairiah et al. (2011) sebagai berikut:

$$
\text { Total BK }=\frac{B K \text { subsampel }(g)}{B B \text { subsampel }(g)} x \text { Total BB }(g)
$$

BK adalah berat kering (g), BB adalah berat basah (g)

Perhitungan biomassa pohon mati menggunakan rumus:

$$
B_{p m}=f \times B_{p}
$$

$B_{p m}$ adalah biomassa pohon mati, f adalah faktor koreksi (kelas $1=0.9$, kelas $2=0.8$, dan kelas $3=0.7$ ), $\mathrm{B}_{\mathrm{p}}$ adalah persamaan alometrik yang digunakan pada pohon hidup dalam penelitian.

\begin{tabular}{|c|c|c|}
\hline $\begin{array}{l}\text { Jenis } \\
\text { Pohon }\end{array}$ & Model Alometrik & Sumber \\
\hline Pohon & $\mathrm{W}=0.11 \rho \mathrm{D}^{2.62}$ & $\begin{array}{l}\text { Ketterings et al. } \\
\text { (2001) }\end{array}$ \\
\hline Pohon & $\begin{array}{l}\mathrm{W}=\exp [-2.134 \\
+2.530 \times \ln (\mathrm{D})]\end{array}$ & Brown (1997) \\
\hline $\begin{array}{l}\text { Kopi } \\
\text { dipangkas }\end{array}$ & $\mathrm{W}=0.281 \mathrm{D}^{2.06}$ & $\begin{array}{l}\text { Arifin }(2001) \\
\text { dalam Hairiah et } \\
\text { al. }(2011)\end{array}$ \\
\hline Kakao & $\mathrm{W}=0.281 \mathrm{D}^{1.98}$ & $\begin{array}{l}\text { Yuliasmara et } \\
\text { al. (2009) }\end{array}$ \\
\hline $\begin{array}{l}\text { Kelapa } \\
\text { Sawit }\end{array}$ & $\begin{array}{l}\mathrm{W}=0.0976 \mathrm{H}+ \\
0.0706\end{array}$ & ICRAF (2009) \\
\hline Palem & $\mathrm{W}=4.5+7.7 \mathrm{H}$ & $\begin{array}{l}\text { Frangi \& Lugo } \\
\text { (1985) }\end{array}$ \\
\hline
\end{tabular}

Tabel 1 Rumus-rumus alometrik untuk menduga biomassa di berbagai tipe penggunaan lahan di Kabupaten Pesisir Barat

Keterangan: $\mathrm{W}=$ Biomassa $(\mathrm{kg} /$ pohon$)$

$\mathrm{D}=$ diameter $(\mathrm{cm})$

$\rho=$ kerapatan jenis kayu $(\mathrm{g} / \mathrm{cm})$

$\mathrm{H}=$ tinggi pohon $(\mathrm{cm})$
Perhitungan biomassa kayu mati menggunakan rumus:

$$
\begin{gathered}
B_{k m}=V_{k m} \times B J_{k m} \\
V_{k m}=0.25 \pi\left(\frac{d p+d u}{2 \times 100}\right)^{2} \times p
\end{gathered}
$$

$B_{k m}$ adalah biomassa kayu mati $(\mathrm{kg}), \mathrm{V}_{\mathrm{km}}$ adalah volume kayu mati $(\mathrm{cm}), B J_{k m}$ adalah berat jenis kayu mati $\left(\mathrm{kg} / \mathrm{m}^{3}\right), V_{k m}$ adalah volume kayu mati $\left(\mathrm{m}^{3}\right), d p$ adalah diameter pangkal kayu mati $(\mathrm{cm}), d u$ adalah diameter ujung kayu mati $(\mathrm{cm}), p$ adalah panjang kayu mati (m) $\pi=\frac{22}{7}$ atau 3.14.

Perhitungan biomassa pohon menggunakan persamaan alometrik yang telah tersedia pada Tabel 1 . Nilai kerapatan jenis kayu diakses melalui website db.worldagroforetry.org.

\section{Analisis simpanan karbon dan serapan karbondioksida}

Perhitungan simpanan karbon dari biomassa menggunakan rumus BSN (2011) sebagai berikut:

$$
C_{b}=B x \% C
$$

$C_{b}$ adalah simpanan karbon dari biomassa $(\mathrm{kg})$, B adalah total biomassa $(\mathrm{kg}), \quad \% C$ adalah nilai persentase kandungan karbon sebesar 0.47.

Perhitungan serapan $\mathrm{CO}_{2}$, menggunakan rumus (Manuri et al. 2011) sebagai berikut: Serapan $\mathrm{CO}_{2}=$ simpanan karbon x 3.67 .

\section{HASIL DAN PEMBAHASAN}

\section{Komposisi dan Dominansi Jenis}

Richards (1966) menggunakan istilah komposisi jenis untuk menyatakan keberadaan jenis-jenis pohon di dalam hutan. Komposisi jenis merupakan kekayaan floristik hutan tropika yang sangat erat kaitannya dengan kondisi lingkungan seperti iklim, tanah, dan cahaya, dimana faktor tersebut membentuk suatu tegakan yang klimaks (Mueller-Dumbois \& Ellenberg 1974). Komposisi jenis penyusun berdasarkan analisis vegetasi di hutan Taman Nasional Bukit Barisan Selatan (TNBBS) ditemukan 83 jenis tumbuhan yang tergolong ke dalam 37 suku, di kebun sawit sebanyak 9 jenis tumbuhan yang tergolong ke dalam 8 suku, di kebun kopi ditemukan 17 jenis tumbuhan yang tergolong ke dalam 11 suku, dan di agroforestri repong damar ditemukan 73 jenis tumbuhan yang tergolong ke dalam 33 suku. Penemuan jenis tumbuhan di Resort Balai Kencana ini memberikan hasil yang lebih sedikit dibandingkan penelitian yang dilakukan di kawasan Gunung Sekincau TNBBS oleh Solihah et. al. (2014) yaitu 32 suku dan 89 jenis. Hal ini kemungkinan disebabkan lokasi yang berbeda menyebabkan hasil pengamatan yang diperoleh juga berbeda. Jumlah individu damar mata kucing (Shorea javanica) sebagai jenis yang paling banyak ditemui di agroforestri repong damar ini memberikan gambaran bahwa komposisi yang ada mirip dengan hutan TNBBS khususnya di zona tradisional. Hal ini dapat dilihat dengan membandingkan hasil penelitian Yulizar (2016) yang melaporkan komposisi damar mata kucing ( $S$. javanica) 
pada tingkat pertumbuhan semai 50 ind/ha, pancang 16 ind/ha, tiang $12 \mathrm{ind} / \mathrm{ha}$ dan pohon $36 \mathrm{ind} / \mathrm{ha}$, sedangkan di agroforestri repong damar berdasarkan hasil pengamatan yaitu pada tingkat semai 14900 ind/ha, pancang $112 \mathrm{ind} / \mathrm{ha}$, tiang $92 \mathrm{ind} / \mathrm{ha}$, dan pohon 144 ind/ha. Hal ini diduga karena agroforestri repong damar ini lokasinya berbatasan dengan zona tradisional TNBBS.

Jenis tumbuhan yang memiliki nilai Indeks Nilai Penting (INP) tertinggi merupakan jenis dominan. Indriyanto (2008) menyatakan bahwa besarnya nilai INP menandakan besar atau tidaknya pengaruh spesies tersebut dalam suatu komunitas tumbuhan. Hasil perhitungan nilai INP di hutan TNBBS yaitu pasang (Quercus blumeana) mendominasi pada tingkat tiang $(47.71 \%)$ dan pohon (35.58\%), simpur (Dillenia excelsa) mendominasi pada tingkat pancang (29.35\%), salai (Glochidion obscurum) mendominasi pada tingkat semai $(69.85 \%)$, dan rilik (Phrynium capitatum) mendominasi tumbuhan bawah $(35.46 \%)$. Kebun sawit dengan jenis dominan adalah sawit (Elaeis guineensis) memiliki INP sebesar $300 \%$, sedangkan teki (Cyperus rotundus) mendominasi tumbuhan bawah (43.44\%). Tanaman kopi (Coffea robusta) mendominasi dengan INP sebesar 210.56\%. Nilai INP tertinggi pada agroforestri repong damar adalah damar mata kucing (Shorea javanica) mendominasi tingkat tingkat semai (52.38\%), tiang (128.17\%), dan pohon (140.31\%), kayu samang (Diospyros macrophylla) mendominasi pada tingkat pancang $(29.81 \%)$, dan rangkeni (Selaginella plani) mendominasi tumbuhan bawah ( $83.21 \%)$.

Damar mata kucing ( $S$. javanica) merupakan jenis yang konsisten dominan di setiap tingkat pertumbuhan yang menyusun komposisi jenis di agroforestri repong damar. Lubis (2005) menyatakan bahwa disebut repong damar karena pohon damar merupakan tegakan yang dominan jumlahnya pada setiap bidang repong. Lensari (2011) juga melaporkan bahwa pada tingkat pohon jenis damar memiliki INP tertinggi dibandingkan dengan jenis tanaman yang lainnya yaitu sebesar $85.58 \%$. Whitmore (1990) menyatakan bahwa Dipterocarpaceae mempunyai respon cepat tumbuh dengan meningkatnya cahaya dan mampu berkompetisi dengan tumbuhan yang lebih tinggi.

Hutan TNBBS memiliki komposisi jenis yang berbeda apabila dibandingkan jenis-jenis yang dominan antar tingkat pertumbuhan. Jenis tumbuhan salai ( $G$. obscurum) yang mendominasi pada tingkat semai tidak mendominasi pada tingkat pancang, tiang ataupun pohon. Hal ini menunjukkan adanya perubahan komposisi jenis yang menduduki tiap strata pertumbuhan, dan telah terjadi gangguan terhadap proses regenerasi jenis dominan pada tingkat semai. Pasang ( $Q$. blumeana) merupakan jenis yang selalu hadir pada setiap tingkatan. Hal ini menunjukkan bahwa jenis-jenis tersebut mempunyai regenerasi yang paling baik. Jenis-jenis dominan pada tingkat pohon yang telah mencapai puncak pertumbuhan akan digantikan dengan jenis-jenis pada tingkat tiang dengan komposisi berbeda akan naik menjadi tingkat pohon, begitu juga seterusnya pada tingkatan di bawahnya. Hal ini menyebabkan komposisi pohon dominan di hutan TNBBS akan bergeser di masa yang akan datang. Faktor yang memengaruhi variasi nilai INP diantaranya lingkungan tempat tumbuh seperti suhu, kelembaban, kemampuan berkompetisi dengan jenis lainnya dalam perebutan hara, sinar matahari dan ruang tumbuh, yang sangat memengaruhi pertumbuhan diameter batang pohon.

\section{Keanekaragaman Jenis}

Keanekaragaman jenis merupakan parameter untuk membandingkan dua komunitas dalam mempelajari pengaruh gangguan biotik, mengetahui tingkatan suksesi atau kestabilan suatu komunitas. Gambar 1a menunjukkan bahwa keanekaragaman jenis yang tinggi dari ke empat lokasi adalah pada tingkat tiang (3.26) dan pohon (3.27) di hutan TNBBS. Keanekaragaman jenis yang sedang terdapat di hutan TNBBS pada tingkat pancang (2.86) dan tumbuhan bawah (2.07), serta pada agroforestri repong damar pada tingkat semai (2.20), pancang (2.71), dan pohon (2.00). Keanekaragaman jenis tergolong rendah terdapat di hutan TNBBS pada tingkat semai (1.80), di kebun sawit tingkat pohon (0) dan tingkat tumbuhan bawah (1.90), serta di kebun kopi (0.34).

Keanekaragaman jenis yang tinggi di hutan TNBBS menunjukkan bahwa fungsi dan proses ekologi masih berjalan normal sehingga tekanan lingkungan belum memengaruhi kestabilan ekosistem. Odum (1993) menyatakan bahwa keanekaragaman jenis akan tetap tinggi apabila perlindungan mutlak terhadap kawasan terjaga dengan mengurangi tekanan-tekanan fisik dari

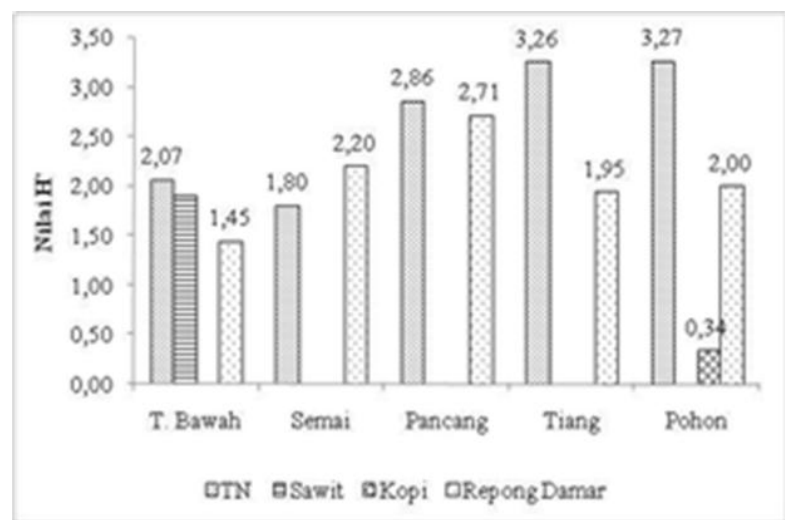

(a)

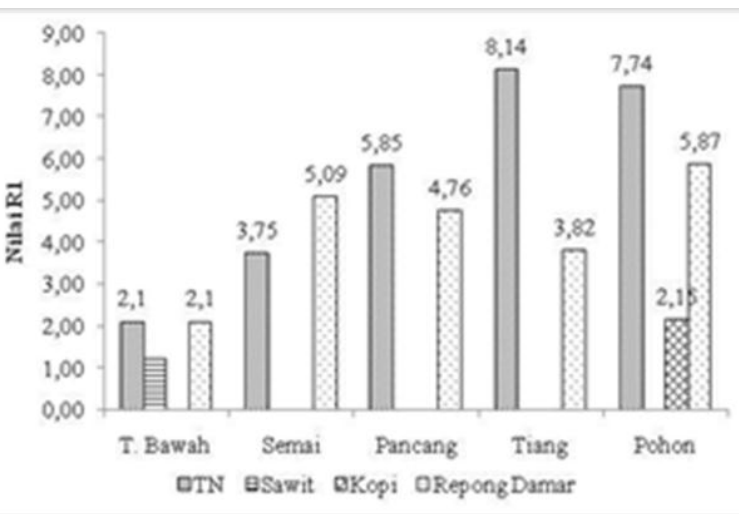

(b)

Gambar 1 (a) Nilai indeks keanekaragaman jenis (b) Nilai indeks kekayaan jenis 
manusia terhadap kawasan sehingga proses ekologis tetap bertahan tanpa campur tangan manusia secara langsung.

Kebun sawit dan kopi yang memiliki keanekaragaman jenis yang tergolong rendah diduga disebabkan pengelolaan ekosistem yang secara fisik terkendali dan intensif. Pemilihan jenis tumbuhan yang dikembangkan berdasarkan pertimbangan kebutuhan dan nilai ekonomi. Keanekaragaman jenis dipengaruhi jumlah jenis dan kelimpahan relatif dari setiap jenisnya. Variasi nilai indeks keanekaragaman pada berbagai tingkatan pertumbuhan yang terjadi berhubungan dengan karakteristik tempat tumbuh dan aktivitas yang berlangsung di dalam komunitas ekosistem tersebut. Faktor- faktor yang memengaruhi perbedaan keanekaragaman jenis antara lain kondisi habitat dan adanya gangguan baik secara alami ataupun karena kegiatan manusia (Pratiwi 1987), ketersediaan dan pemanfaatan nutrisi (Sastrawidjaya 1991), ketinggian tempat (Rozak et al. 2016).

\section{Kekayaan Jenis}

Kekayaan jenis adalah jumlah jenis dalam suatu luasan areal tertentu. Kriteria nilai indeks kekayaan jenis (R1) yaitu: 1) rendah, jika nilai $R 1<3.5,2$ ) sedang, jika nilai $\mathrm{R} 1=3.5-5,3)$ tinggi, jika nilai $\mathrm{R} 1>5$. Indeks kekayaan semakin besar apabila semakin banyak jumlah jenis yang ditemukan. Gambar $1 \mathrm{~b}$ menunjukkan bahwa indeks kekayaan jenis tergolong tinggi terdapat di hutan TNBBS pada tingkat pancang (5.85), tiang (8.14), dan pohon (7.74) dan di agroforestri repong damar pada tingkat pohon (5.70) dan semai (5.85), tergolong sedang terdapat di hutan TNBBS pada tingkat semai (3.75) dan agroforestri repong damar pada tingkat pancang (4.76) dan tiang (3.82), tergolong rendah di hutan TNBBS pada tingkat tumbuhan bawah (2.10), di kebun sawit (1.22), di kebun kopi (2.15) dan di agroforestri repong damar pada tingkat tumbuhan bawah.

\section{Kesamaaan Komunitas}

Indeks Kesamaan Komunitas (IS) merupakan nilai untuk mengetahui kesamaan relatif komposisi jenis dari dua tegakan yang dibandingkan pada masing-masing tingkat pertumbuhan. Ludwig dan Reynolds (1988) menyatakan bahwa kesamaan jenis pada dua lokasi dikatakan sama apabila nilai kesamaan dari dua lokasi > $50 \%$, sedangkan bila nilainya berada $<50 \%$ maka dua lokasi yang dibandingkan berbeda nyata atau tidak sama. Hasil perhitungan yang disajikan pada Tabel 2 menunjukkan bahwa semua lokasi tidak memiliki kesamaaan

\section{Simpanan Karbon dan Serapan Karbondioksida}

Pengukuran jumlah karbon yang tersimpan dalam biomassa pada suatu lahan dapat menggambarkan banyaknya tanaman menyerap $\mathrm{CO}_{2}$ dari atmosfer, sedangkan dalam bagian tumbuhan yang telah mati (nekromasa) menggambarkan $\mathrm{CO}_{2}$ yang tidak dilepaskan ke udara lewat pembakaran. Potensi simpanan karbon dan serapan karbondioksida pada lokasi penelitian tersaji pada Tabel 3. Simpanan karbon pada setiap lokasi penelitian memiliki jumlah yang berbeda-beda, hal ini disebabkan karena perbedaan

Tabel 2. Nilai indeks kesamaan komunitas

\begin{tabular}{llccccc}
\hline No & Lokasi & \multicolumn{5}{c}{ Indeks Kesamaan Komunitas (\%) } \\
\cline { 3 - 6 } & & $\begin{array}{c}\text { Tumbuhan } \\
\text { Bawah }\end{array}$ & Semai & Pancang & Tiang & Pohon \\
\hline 1 & TN vs S & 10.53 & - & - & - & 0.00 \\
2 & TN vs RD & 32.00 & 11.76 & 17.39 & 7.86 & 29.33 \\
3 & TN vs K & - & - & - & - & 6.90 \\
4 & RD vs S & 18.18 & - & - & - & 0.00 \\
5 & RD vs K & - & - & - & - & 27.45 \\
6 & S vs K & - & - & -0.00 \\
\hline
\end{tabular}

TN=Taman Nasional, $\mathrm{S}=$ Sawit, $\mathrm{RD}=$ Repong Damar, $\mathrm{K}=$ Kopi

Tabel 3 Potensi simpanan karbon dan serapan karbondioksida pada penelitian

\begin{tabular}{|c|c|c|c|c|c|c|c|c|}
\hline & \multicolumn{4}{|c|}{ Simpanan Karbon (ton/ha) } & \multicolumn{4}{|c|}{ Serapan $\mathrm{CO}_{2}\left(\right.$ ton $\left.\mathrm{CO}_{2} / \mathrm{ha}\right)$} \\
\hline & TN & $\mathrm{S}$ & $\mathrm{K}$ & $\mathrm{RD}$ & $\mathrm{TN}$ & $\mathrm{S}$ & $\mathrm{K}$ & RD \\
\hline \multicolumn{9}{|l|}{ Biomassa } \\
\hline Tumbuhan & - & 0.80 & - & 0.56 & - & 2.93 & - & 2.05 \\
\hline \multicolumn{9}{|l|}{ Bawah } \\
\hline Pancang & 0.21 & - & - & 0.31 & 0.76 & - & - & 1.13 \\
\hline Tiang & 3.09 & - & - & 17.16 & 11.36 & - & - & 62.97 \\
\hline Pohon & 77.02 & 6.61 & 34.85 & 224.41 & 282.65 & 4.43 & 23.35 & 824.64 \\
\hline Subtotal & 80.32 & 7.40 & 34.85 & 242.43 & 294.77 & 7.36 & 23.35 & 890.79 \\
\hline \multicolumn{9}{|l|}{ Nekromassa } \\
\hline Serasah & 1.62 & 1.71 & 1.14 & 2.48 & 5.96 & 6.28 & 4.17 & 9.10 \\
\hline Pohon mati & 3.87 & - & - & 0.33 & 14.20 & - & - & 1.22 \\
\hline Subtotal & 5.49 & 1.71 & 1.14 & 2.81 & 20.16 & 6.28 & 4.17 & 10.32 \\
\hline Total & 85.81 & 9.12 & 35.98 & 245.25 & 314.93 & 13.64 & 27.52 & 901.11 \\
\hline
\end{tabular}

TN=Taman Nasional, $\mathrm{S}=$ Sawit, RD= Repong Damar, K=Kopi 
kerapatan jenis tumbuhan. Istomo dan Farida (2017) menyatakan bahwa biomassa tegakan dan potensi karbon semakin meningkat dengan meningkatnya kerapatan tegakan. Mutuo et al. (2005) menyatakan bahwa perbedaan ini mungkin disebabkan oleh adanya perbedaan struktur, komponen penyusun, kerapatan populasi pohon dan adanya perbedaan umur pohon. Jenis vegetasi juga berpengaruh terhadap simpanan karbon pada suatu sistem penggunaan lahan.

Hutan TNBBS memiliki serapan $\mathrm{CO}_{2}$ tertinggi pada tingkat pohon adalah merantang (Campnosperma sp.) (46.47 ton/ha), pasang ( $Q$. bluemana) pada tingkat tiang (1.65 ton/ha) dan tingkat pancang (0.23 ton/ha). Serapan $\mathrm{CO}_{2}$ pohon sawit (E. guineensis) sebesar 4.43 ton/ha dan kopi ( $C$. robusta) sebesar 12.62 ton/ha. Agroforestri repong damar memiliki serapan $\mathrm{CO}_{2}$ tertinggi pada tingkat pohon adalah damar mata kucing ( $S$. javanica) (616.50 ton/ha), tingkat tiang adalah pinang (Areca catechu) (57.68 ton/ha), tingkat pancang adalah bayur (Pterospermum javanicum) (0.45 ton/ha).

Hasil penelitian di kebun sawit nilainya lebih besar daripada penelitian yang dikemukakan oleh Noordwijk et al. (2010) yaitu nilai serapan karbon sawit rata-rata 2.09 ton/tahun. Berbeda dengan hasil penelitian Syahrinudin (2005) perkebunan sawit di Jambi memiliki cadangan karbon 16.60 ton/ha pada umur 3 tahun, 49.30 ton/ha pada umur 10 tahun, 65.30 ton/ha pada umur tanam 20 tahun dan mencapai 84.00 ton/ha pada umur 30 tahun. Tjitrosemito dan Mawardi (2001) dalam penelitiannya juga mengemukakan kandungan karbon kelapa sawit pada umur 19 tahun sekitar 40.28 ton/ha. Variasi nilai yang diperoleh pada setiap hasil penelitian tersebut sesuai dengan luasan lokasi penelitian dan umur kelapa sawit.

Total simpanan karbon di kebun kopi sebesar 35.98 ton/ha dengan serapan $\mathrm{CO}_{2}$ sebesar 27.52 ton/ha. Hasil yang berbeda ditunjukkan pada agroforestri multistrata berbasis kopi di Indonesia rata-rata adalah 43.00 ton/ha, agroforestri sederhana (naungan tunggal) berbasis kopi lahan milik petani dan kebun percobaan masing-masing adalah 23.00 dan 38.00 ton/ha, sedangkan pada lahan kopi monokultur cadangan karbonnya rata-rata hanya 13.00 ton/ha (Hairiah \& Rahayu 2010).

Total simpanan karbon di lokasi penelitian sebesar 376.16 ton/ha dengan serapan $\mathrm{CO}_{2}$ sebesar 1257.20 ton/ha. Agroforestri repong damar memiliki simpanan karbon dan serapan $\mathrm{CO}_{2}$ tertinggi dibanding lokasi yang lainnya. Hal ini diduga karena penyusun vegetasi yang ada di agroforestri repong damar didominasi oleh damar mata kucing ( $S$. javanica) yang memiliki diameter yang cukup besar bisa mencapai $143.31 \mathrm{~cm}$. Diameter dengan nilai yang tinggi akan memengaruhi biomassa pohon karena pengukuran biomassa pohon yang menggunakan persamaan alometrik berdasarkan pada diameter batang. Yamani (2013) menyatakan bahwa kandungan biomassa terbesar adalah pada tingkat pohon atau tegakan yang memiliki diameter $>20 \mathrm{~cm}$. Palm et al. (1999) melaporkan sistem agroforestri di daerah tropis mampu menambah hingga $35 \%$ persediaan $\mathrm{C}$ dari hutan yang sebelumnya dikonversi, dibandingan hanya $12 \%$ jika hanya ditanam tanaman pangan dan pakan ternah. Montagnini dan Nair (2004) juga melaporkan bahwa penyimpanan karbon rata-rata pada praktek agroforestri diperkirakan 9, 21, 50, dan 63 ton/ha di daerah semi arid, sub humid, humid, dan temperate.

Simpanan karbon di hutan pada penelitian ini lebih kecil daripada di agroforestri repong damar. Besaran nilai simpanan karbon di hutan dipengaruhi diameter dari vegetasi penyusunnya, dimana pada lokasi penelitian lebih kecil dibandingkan dengan vegetasi di agroforestri repong damar. Dharmawan (2010) melaporkan pada hutan alam primer dan sekunder di Gunung Gede Pangrango dengan rata-rata cadangan karbon atas permukaan sekitar 103.16 ton/ha dan 113.20 ton/ha. Cadangan karbon pada berbagai kelas penutupan lahan di hutan alam berkisar 7.50 ton $\mathrm{C} /$ ha-264.70 ton C/ha dan kawasan non hutan pada berbagai jenis tanaman dan umur berkisar 0.70-932.96 ton/ha (Masripatin et al. 2010).

\section{SIMPULAN DAN SARAN}

\section{Simpulan}

Hutan TNBBS memiliki keanekaragaman jenis tumbuhan tertinggi dengan ditemukannya 83 jenis tumbuhan (37 suku). Agroforestri repong damar memiliki keanekaragaman jenis yang tidak berbeda jauh dengan di hutan TNBBS yaitu sebanyak 73 jenis tumbuhan (33 suku). Komposisi jenis tumbuhan yang berbeda pada setiap penggunaan lahan dipengaruhi oleh perbedaan pengelolaan. Semakin intensif pengelolaan maka keanekaragaman jenis dan kekayaan jenis rendah. Hasil penelitian menunjukkan bahwa nilai simpanan karbon pada suatu penggunaan lahan dipengaruhi oleh keanekaragaman jenis tumbuhan, diameter pohon penyusun, dan kerapatan individu. Semakin besar diameter pohon penyusun dan jumlah individu penyusunnya lebih banyak maka proses penyerapan karbondioksidanya semakin besar sehingga akan memberikan nilai simpanan karbon yang lebih besar. Total potensi simpanan karbon di atas permukaan tanah pada lokasi penelitian di Kabupaten Pesisir Barat adalah 376.16 ton/ha dan serapan $\mathrm{CO}_{2}$ adalah 1257.20 ton/ha dengan serapan $\mathrm{CO}_{2}$ tertinggi terdapat pada jenis tumbuhan di lokasi agroforestri repong damar sebesar 901.11 ton/ha

\section{Saran}

Keanekaragaman jenis tumbuhan yang terdapat di lokasi penelitian memberikan gambaran besaran nilai penyerapan $\mathrm{CO}_{2}$ yang tersimpan sebagai simpanan karbon di atas permukaan tanah yang dapat berguna dalam penurunan emisi karbon di Kab.Pesisir Barat. Perlu dilakukan pengukuran bahan organik tanah untuk mengetahui biomasa dan kandungan karbon pada lokasi penelitian secara holistik. 


\section{DAFTAR PUSTAKA}

[Bappeda] Badan Perencanaan Pembangunan Daerah Kabupaten Pesisir Barat. 2015. Profil Investasi Berbasis Klaster Kabupaten Pesisir Barat Tahun 2015. Pesisir Barat (ID): Badan Perencanaan Pembangunan Daerah Kabupaten Pesisir Barat.

[Bappenas] Badan Perencanaan Pembangunan Nasional. 2010. Naskah Akademis Rencana Aksi Nasional Penurunan Emisi Gas Rumah Kaca 2010-2020. Jakarta (ID): Badan Perencanaan Pembangunan Nasional.

Brown S. 1997. Estimating biomass and biomass change of tropical forests: a primer. Rome (IT): FAO Forestry paper 134, FAO.

[BSN] Badan Standardisasi Nasional. 2011. SNI 7722:2011: Pengukuran dan penghitungan cadangan karbon-Pengukuran lapangan untuk penaksiran cadangan karbon hutan. Jakarta (ID): Badan Standardisasi Indonesia.

Dharmawan IWS. 2010. Estimation of aboveground biomass carbon stock in project pilot plot of Conservation International-Daikin at Nagrak Resort, Gede Pangrango National Park. Jakarta (ID): Conservation International and Daikin.

Frangi J, Lugo A. 1985. Ecosystem dynamics of subtropical floodplain forest. Ecological Monographs. 55 (3): 351-369.

Hairiah K, Rahayu S. 2010. Mitigasi perubahan iklim agroforestri kopi untuk mempertahankan cadangan karbon lanskap. Dalam Prosiding Seminar Kopi 2010. Bali, 4-5 Oktober 2010. Hlm.1-31.

Hairiah K, Ekadinata A, Sari RR, Rahayu S. 2011. Petunjuk Praktis Pengukuran Cadangan Karbon dari Tingkat Plot ke Tingkat Bentang Lahan. Edisi Ke-2. Malang (ID): World Agroforestry Centre ICRAF, SEA Regional Office,University of Brawijaya, Indonesia.

[ICRAF] World Agroforestry Centre. 2009. Cadangan Karbon di Kabupaten Nunukan, Kalimantan Timur: Monitoring Secara Spasial dan Pemodelan. Bogor (ID): World Agroforestry Centre.

Indriyanto. 2008. Ekologi Hutan. Jakarta (ID) : PT Bumi Aksara.

Istomo, Farida NE. 2017. Potensi simpanan karbon di atas permukaan tanah tegakan Acacia nilotica $\mathrm{L}$. (Wild) ex. Del. di Taman Nasional Baluran, Jawa Timur. JPSL. 7 (2): 155-162.

Ketterings QM, Coe R, van Noordwijk M, Ambagau Y, Palm CA. 2001. Reducing uncertainty in the use of allometric biomass equations for predicting aboveground tree biomass in mixed secondary forests. Forest Ecology and Management. 120: 199-209.

[KLHK] Kementerian Lingkungan Hidup dan Kehutanan. 2017. Deforestasi Indonesia Tahun 2015-2016. Jakarta (ID): Direktorat Inventarisasi dan Pemantauan Sumber Daya Hutan. Direktorat Jenderal Planologi Kehutanan dan Tata Lingkungan. Kementerian Lingkungan Hidup dan Kehutanan.

Lensari D. 2011. Kinerja pengelolaan Repong Damar ditinjau dari aspek ekologi, sosial dan ekonomi [tesis]. Bogor (ID): Institut Pertanian Bogor.
Lubis Z. 2005. Pengetahuan lokal dalam sistem pengelolaan sumber daya alam berkelanjutan: Warisan budaya yang terancam hilang. $J$ Antropologi Sosial Budaya ETNOVISI. 1: 48-54.

Ludwig JA, Reynolds JF. 1988. Statistical Ecology: A Primer on Methods and Computing. New York (US): J Wiley.

Manuri S, Putra CAS, Saputra AD. 2011. Tehnik Pendugaan Cadangan Karbon Hutan. Palembang (ID): Merang REDD Pilot Project, German International Cooperation - GIZ.

Margalef R. 1958. Temporal succession and spatial heterogenety in phytoplankton. In : Perspectives in Marine Biology. Buzzati-Traverso (ed). Berkeley: Univ. Calif. Press. Berkeley.

Masripatin N, Ginoga K, Pari G, Dharmawan WS, Siregar CA, Wibowo A, Puspasari D, Utomo AS, Sakuntala D, Lugina M et al. 2010. Cadangan Karbon pada berbagai Tipe Hutan dan Jenis Tanaman di Indonesia. Bogor (ID): Pusat Penelitian dan Pengembangan Perubahan Iklim Kementerian Kehutanan.

Montagnini F, Nair PKR. 2004. Carbon sequestration: An underexploited enviromental benefit of agroforestry system. Agroforest Syst. 61: 281-295

Mueller-Dombois D, Ellenberg H. 1974. Aims and Methods of Vegetation Ecology. New York (US): J Wiley.

Mutuo PK, Cadisch G, Albrecht A, Palm CA, Verchot L. 2005. Potential agroforestry for carbon sequestration and mitigation of greenhouse gas emissions from soils in the tropics. Nutrient cycling in Agroecosystems. 71(1): 43-54.

Odum EP. 1993. Dasar-dasar Ekologi. Samingan Tj, penerjemah; Srigandono B, editor. Yogyakarta (ID): Gadjah Mada Press. Terjemahan dari: Fundamental of Ecology.

Palm CA, Woomer PL, Alegre J, Arevalo L, Castilla C, Cordeiro DG, Feigl B, Hairiah K, Kotto-Same J, Mendes A, et al. 1999. Carbon sequestrations and trace gas emissions in slash and burn alternative land uses in the humid tropic: ASB Climate Change Working Group Report. Final Report Phase II. Nairobi, Kenya (tZA): ICRAF.

Pratiwi. 1987. Analisis komposisi jenis pohon di Taman Nasional Gunung Gede Pangrango Jawa Barat. Buletin Penelitian Hutan. 4(8): 28-34.

Richards PW. 1966. The Tropical Rain Forest and Ecological Study. New York (US): Cambridge Univ Pr.

Rozak AH, Astutik S, Mutaqien Z, Widyatmoko D, Sulistyawati. 2016. Kekayaan jenis pohon di hutan Taman Nasional Gunung Gede Pangrango, Jawa Barat. Jurnal Penelitian Hutan dan Konservasi Alam. 13 (1): 1-14.

Solihah SM, Wardani FF, Rahayu S. 2014. Variasi struktur dan komposisi pohon pada petak cuplikan vegetasi di kawasan Gunung Sekincau Bukit Barisan Selatan, Lampung Barat. Buletin Kebun Raya 17:2.

Syahrinudin. 2005. The potential of oil palm and forest plantations for carbon sequestration on degraded land in Indonesia [Disertasi]. Vlek PLG, Denich 
M, Martius C, Rodgers C, van de Giesen N, editor. Göttingen (DE): Cuvillier Verlaag Göttingen.

Takimoto A, Nair VD, Nair PKR. 2009. Contribution of trees to soil carbon sequestration under agroforestry systems in the West African Sahel. Agrofor Syst. 76:11-25.

Tjitrosemito S, Mawardi. 2001. Terrestrial Carbon Stock in Oil Palm Plantation. Bogor (ID): Biotrop

van Noordwijk M, Dewi S, Khasanah N, Ekadinata A, Rahayu S, Caliman JP, Sharma M, Suharto R. 2010. Estimating the Carbon Footprint of Biofuel Production from Oil Palm: Methodology and Results from Two Sites in Indonesia. Di dalam: Caliman JP, Yuan YY, Buana L, editor. 2nd International Conference on Oil Palm and the Environment; 2010 February 23-25; Bali, Indonesia. Jakarta (ID): ICOPE. hlm 48-81.
Whitmore TC. 1990. An Introduction to Tropical Rain Forest. New York (US): Oxford Univ Pr.

Yamani A. 2013. Studi kandungan karbon pada hutan alam sekunder di Hutan Pendidikan Mandiangin Fakultas Kehutanan UNLAM. J Hutan Tropis. 1 (1): 85-91.

Yuliasmara F, Wibawa A, Prawoto AA. 2009. Karbon tersimpan pada berbagai umur dan sistem pertanaman kakao: pendekatan allometrik. Pelita Perkebunan. 25(2): 86-100.

Yulizar, Hikmat A, Koesmaryandi N. 2014. Konservasi damar mata kucing (Shorea javanica) berbasis masyarakat di zona tradisional Taman Nasional Bukit Barisan Selatan. Media Konserv. 19 (2): 7380 . 